\title{
Host Range of Oidium lycopersicum on Selected Solanaceous Species in Connecticut
}

J. A. LaMondia, Department of Plant Pathology and Ecology, Connecticut Agricultural Experiment Station, Windsor 06095; and V. L. Smith and S. M. Douglas, Department of Plant Pathology and Ecology, Connecticut Agricultural Experiment Station, New Haven 06504

\begin{abstract}
LaMondia, J. A., Smith, V. L., and Douglas, S. M. 1999. Host range of Oidium lycopersicum on selected solanaceous species in Connecticut. Plant Dis. 83:341-344.

Powdery mildew of tomato in Connecticut was identified as Oidium lycopersicum based on anamorph characteristics. On tomato, conidia were most often formed singly or in pairs on unbranched conidiophores. Mycelium was hyaline and measured 5 to $7 \mu \mathrm{m}$. Cleistothecia were not found. This fungus caused disease on a number of tomato cultivars ranging in size from seedlings to mature plants under greenhouse and field conditions. Eastern black nightshade, eggplant, tobacco, and potato were infected in the greenhouse. Reciprocal inoculation experiments between tomato and nightshade and eggplant and tobacco demonstrated cross-infectivity, but the size and number of conidia per conidiophore varied between hosts. Conidia from tobacco, eggplant, and nightshade averaged 37.8 by $19.1 \mu \mathrm{m}$ ( $\mathrm{SE}=0.5$ and 0.2 , respectively) with a $95 \%$ confidence interval (CI) of 35.5 to 40.0 by 18.1 to $20.3 \mu \mathrm{m}(n=300)$. Conidia from tomato were smaller, averaging 33.6 by $18.2 \mu \mathrm{m}$ ( $\mathrm{SE}=0.3$ and 0.2 , respectively) with a $95 \% \mathrm{CI}$ of 32.7 to 34.4 by 17.5 to $18.9 \mu \mathrm{m}(n=300)$. Conidia from potato averaged 32.4 by $16.6 \mu \mathrm{m}(\mathrm{SE}=0.4$ and 0.2 , respectively) with a $95 \%$ CI of 31.5 to 33.3 by 16.3 to $17.0 \mu \mathrm{m}(n=100)$. There were significant differences in percent leaf infection and powdery mildew disease ratings between $L y$ copersicon esculentum cultivars and Lycopersicon breeding lines under both greenhouse and field conditions. Most commercial tomato cultivars were severely affected by powdery mildew. Cultivars such as Rutgers were not as extensively colonized by $O$. lycopersicum, compared to cultivars such as Celebrity and Nema 1200, but the severity of powdery mildew was still quite high. L. hirsutum and the tomato breeding line Hirol 3-21 were the only plants tested that were resistant to $O$. lycopersicum.
\end{abstract}

Additional keywords: Nicotiana tabacum, Solanum melongena, Solanum ptycanthum, Solanum tuberosum

Powdery mildew of tomato (Lycopersicon esculentum L.) is a relatively new disease in North America. This disease may be caused by at least three different fungi. Leveillula taurica (Lév.) G. Arnaud (= Oidiopsis taurica (Lév.) Salmon) is a pathogen of a wide range of host species in warm, arid to semiarid climates in Asia, the Mediterranean, Africa, and more recently the southwest United States (4). Erysiphe orontii Cast (=E. cichoracearum DC. and E. polyphaga Hammarl.) is another polyphagus species common to many host plants in both temperate and tropical regions $(9,14)$. However, the recent disease outbreak reported in eastern North America appears to be due to a morphologically distinct powdery mildew, Oidium lycopersicum Cooke and Mass. Emend. Noordeloos. O. lycopersicum (Erysiphales)

Corresponding author: J. A. LaMondia

E-mail address: lamondia@caes.state.ct.us

Accepted for publication 14 December 1998.

Publication no. D-1999-0128-01R

(C) 1999 The American Phytopathological Society differs from $L$. taurica based on a number of characteristics, including conidiophore and conidia morphology, and from $E$. cichoracearum, which produces conidia in long chains (2).

Tomato plants infected with $O$. lycopersicum were submitted to the Connecticut Agricultural Station Plant Disease and Information Office for diagnosis in 1995 (greenhouse samples), 1996, 1997, and 1998 (greenhouse and field samples) (11). Disease severity in greenhouse-grown tomatoes ranged from light to severe (approximately 90\% of foliage affected in nearly $100 \%$ of plants). The effects on yield were not determined. Symptoms included white superficial mycelium on leaves and stems, followed by desiccation, necrosis, and defoliation. In 1996 and 1997, field-grown tomatoes were severely affected by disease. The vast majority of reports were from home gardens, but commercial production fields were significantly affected in 1998. At least two fields experienced losses despite fungicide use, especially in the inner canopy of late-season tomato plantings. Similar reports of an Erysiphe sp. from Quebec (1) and New York (6) may have been caused by the same or similar fungus. At the same time, Erysiphe spp. producing conidia in chains were reported from Florida (10) and Hungary (7).

The objectives of this research were to identify the powdery mildew fungus from tomato in Connecticut, to investigate the host range of the fungus on certain solanaceous plants, and to determine the host response of selected tomato cultivars under greenhouse and field conditions.

\section{MATERIALS AND METHODS}

Observations of the pathogen were made from fresh leaf material collected from greenhouse- or field-grown plants in Enfield, Windsor, and Hamden, Connecticut. Observations and measurements were made directly using a binocular scope at $45 \times$ magnification or on fresh water mounts at 400 to $1,000 \times$ magnification using an ocular micrometer. A minimum of 100 observations were made for conidia from greenhouse-grown (cvs. Better Boy and Rutgers) or field-grown tomato (cv. Celebrity), eastern black nightshade (Solanum ptycanthum Dunal), eggplant ( $S$. melongena L. cv. Black Pride), broadleaf tobacco (Nicotiana tabacum L. cv. C9), and potato (S. tuberosum L. cv. Superior). A total of 10 to 20 conidia per leaf were measured from leaves of different ages. Detection of fibrosin bodies (15) was attempted after mounting conidia $(n=300)$ from tomato (cvs. Better Boy and Rutgers) in $3 \%$ potassium hydroxide. A total of 20 conidia were recovered and evaluated from each of 15 leaves of different ages.

Cross-inoculation of plants was done by shaking dry conidia onto leaves and placing plants in high-humidity plastic tents on a greenhouse bench. Control plants were treated identically but not inoculated. Conidia from 'Rutgers' tomato were used to inoculate 40-day-old seedlings of 'Rutgers' tomato, eastern black nightshade, 'Black Pride' eggplant, and 'C9' broadleaf tobacco and from 'Superior' potato 2 weeks after shoot emergence. Conidia produced on nightshade, eggplant, and tobacco were inoculated back to tomato plants $(n=12)$. Plants were evaluated for powdery mildew 2 weeks after inoculation.

To evaluate tomato cultivar response, selected cultivars and breeding lines were seeded to plug trays on 22 April 1997. A total of 10 replicate seedlings of each cultivar to be tested were transplanted to 700- 
$\mathrm{cm}^{3}$ pots (21 May) for greenhouse evaluation. An additional 10 replicate seedlings were transplanted to the field (12 June) for field evaluation. Greenhouse-grown plants were evaluated for the number of leaflets with powdery mildew (percent leaf infection) on 10 and 24 June. Field transplants (50 days old) were placed in Merrimac fine sandy loam ( $\mathrm{pH} 5.8$ ) $0.9 \mathrm{~m}$ apart within rows and with $1.8 \mathrm{~m}$ between rows. There were 10 replicate plants per cultivar. Plants were fertilized with $162 \mathrm{~kg}$ of N, $130 \mathrm{~kg}$ of $\mathrm{P}_{2} \mathrm{O}_{5}$, and $162 \mathrm{~kg}$ of $\mathrm{K}_{2} \mathrm{O}$ per hectare preplant on 29 May as cottonseed meal-based fertilizer, staked and not suckered. Plants were side-dressed with $66 \mathrm{~kg}$ of $\mathrm{N}, 53 \mathrm{~kg}$ of $\mathrm{P}_{2} \mathrm{O}_{5}$, and $66 \mathrm{~kg}$ of $\mathrm{K}_{2} \mathrm{O}$ per hectare on 12 June, and $77 \mathrm{~kg}$ of $\mathrm{N}, 62 \mathrm{~kg}$ of $\mathrm{P}_{2} \mathrm{O}_{5}$, and $77 \mathrm{~kg}$ of $\mathrm{K}_{2} \mathrm{O}$ per hectare on 20 June. Plants were rated for disease severity on a scale of 0 to $10(0=$ healthy, $10=$ all leaves infected) on 13 August and 5 September.

\section{RESULTS}

Field development of powdery mildew on tomato in Connecticut included white superficial septate mycelium (5.0 to 7.0, mean $5.7, \mu \mathrm{m}$ wide) with abundant sporulation most commonly on adaxial leaf surfaces, followed by yellowing, necrosis, desiccation of the foliage, and rapid defoliation. Powdery mildew also developed on stems, sepals, and petioles. No powdery mildew was observed on petals or fruit. No cleistothecia were observed in the greenhouse or in the field over 2 years, despite the fact that plants were held for a full year under greenhouse conditions and infected shoots were collected and held overwinter in dry conditions or in fluctuating humidity. Single-celled, hyaline, ellipsoidal conidia occurred, most often singly, on unbranched conidiophores. Conidia ranged in length from 25.6 to $43.2 \mu \mathrm{m}$ (mean $=33.6$, $\mathrm{SE}=0.4)$ and in width from 13.1 to 23.1 $\mu \mathrm{m}$ (mean $=18.2, \mathrm{SE}=0.2 ; n=500)$. Conidiophores $(n=30)$ were 2 to 3 septate (mean $=2.9), 83.1 \mu \mathrm{m}$ (55 to $135 \mu \mathrm{m}$ ) long, and $9.2 \mu \mathrm{m}$ (7.5 to $12.0 \mu \mathrm{m})$ wide. Appressoria were distinct, nipple-shaped to lobed, and sometimes opposite. Haustoria were circular. Fibrosin bodies were not observed and numerous vacuoles were present. Based on these anamorph characteristics, we identified the fungus as Oidium lycopersicum Cooke and Mass. Emend. Noordeloos.

Pathogenicity was confirmed on 2week-old tomato seedlings (cv. Rutgers) inoculated by shaking dry conidia onto the leaves and placed within plastic tents on a greenhouse bench. The inoculated plants developed foliar powdery mildew within 1 week, and sporulation was observed. Control plants were treated identically but were not inoculated and did not develop disease. Susceptible cultivars that were naturally infected included the large-fruited cvs. Better Boy, Better Beef, Better Bush, Celebrity, Rutgers, Ultra Magnum, Ultra Sweet, Whopper, and Yellow Brandywine; cherry-type tomato cvs. Matts Wild Cherry and Sweet Chelsea; and plum-type tomato cvs. Roma, San Marzano, and Super San Marzano.
Eastern black nightshade, eggplant (cv. Black Pride), broadleaf tobacco (cv. C9), and potato (cv. Superior) became infected under greenhouse conditions. However, conidia size differed between hosts (Table 1). Conidia from tobacco, eggplant, and nightshade averaged 37.8 by $19.1 \mu \mathrm{m}$ (SE $=0.5$ and 0.2 , respectively) with a $95 \%$ confidence interval (CI) of 35.5 to $40.0 \mu \mathrm{m}$ by 18.1 to $20.3 \mu \mathrm{m}(n=300)$. Conidia from tomato were smaller, averaging 33.6 by $18.2 \mu \mathrm{m}(\mathrm{SE}=0.3$ and 0.2 , respectively $)$ with a $95 \%$ CI of 32.7 to $34.4 \mu \mathrm{m}$ by 17.5 to $18.9 \mu \mathrm{m}(n=300)$. Conidia from potato averaged 32.4 by $16.6 \mu \mathrm{m}(\mathrm{SE}=0.4$ and 0.2 , respectively) with a $95 \% \mathrm{CI}$ of 31.5 to $33.3 \mu \mathrm{m}$ by 16.3 to $17.0 \mu \mathrm{m}(n=100)$.

Reciprocal inoculation experiments between tomato and nightshade and eggplant and tobacco demonstrated cross-infectivity under greenhouse conditions. All inoculated plants developed powdery mildew while uninoculated plants did not (data not shown). Isolates originally from tobacco had significantly larger conidia when infecting tomato than isolates originally from tomato infecting tobacco (Table 2). Powdery mildew isolates on tomato had fewer $(P=0.001)$ conidia per conidiophore (mean $=1.39$, range 1 to $4 ; 96 \%$ had 1 or 2 conidia per conidiophore) than isolates infecting tobacco inoculated at the same time and held under the same conditions $($ mean $=2.54$, range 1 to $6 ; 54 \%$ had 1 or 2 conidia per conidiophore) $(n=450)$.

Inoculated potato plants developed powdery mildew symptoms within 2 weeks. Symptomatic leaves exhibited considerable

Table 1. Oidium lycopersicum conidia size $(\mu \mathrm{m})$ as influenced by host grown under greenhouse conditions

\begin{tabular}{|c|c|c|c|c|c|c|c|}
\hline Host (cultivar) & Source & Conidia & Mean $^{a}$ & $\mathbf{S D}^{\mathbf{b}}$ & Minimum & Maximum & $95 \% \mathrm{CI}^{\mathrm{c}}$ \\
\hline \multirow[t]{2}{*}{ Tomato (Rutgers) } & \multirow[t]{2}{*}{ Greenhouse, Windsor CT } & Length & 33.7 & 3.8 & 25.0 & 41.3 & $32.9-34.4$ \\
\hline & & Width & 18.5 & 2.3 & 12.5 & 22.5 & $18.0-18.9$ \\
\hline \multirow[t]{2}{*}{ Tomato (Celebrity) } & \multirow[t]{2}{*}{ Field, Enfield, CT } & Length & 33.4 & 3.1 & 27.5 & 42.5 & $32.7-34.0$ \\
\hline & & Width & 17.9 & 2.1 & 13.8 & 22.5 & $17.5-18.3$ \\
\hline \multirow[t]{2}{*}{ Tomato (Better Boy) } & \multirow[t]{2}{*}{ Greenhouse, Hamden CT } & Length & 33.6 & 4.5 & 26.3 & 47.5 & $33.4-35.4$ \\
\hline & & Width & 18.6 & 0.5 & 12.5 & 23.8 & $16.8-17.7$ \\
\hline \multirow[t]{2}{*}{ Nightshade } & \multirow[t]{2}{*}{ Greenhouse, Windsor CT } & Length & 36.6 & 5.3 & 27.5 & 50.0 & $35.5-37.6$ \\
\hline & & Width & 19.9 & 2.0 & 16.3 & 27.5 & $19.5-20.3$ \\
\hline \multirow[t]{2}{*}{ Eggplant (Black Pride) } & \multirow[t]{2}{*}{ Greenhouse, Windsor CT } & Length & 38.9 & 5.4 & 27.5 & 52.5 & $37.9-40.0$ \\
\hline & & Width & 18.5 & 2.1 & 13.8 & 22.5 & $18.1-18.9$ \\
\hline \multirow[t]{2}{*}{ Tobacco (C9) } & \multirow[t]{2}{*}{ Greenhouse, Windsor CT } & Length & 38.0 & 5.0 & 30.0 & 48.8 & $37.0-39.0$ \\
\hline & & Width & 19.0 & 2.1 & 10.0 & 23.8 & $18.5-19.4$ \\
\hline \multirow[t]{2}{*}{ Potato (Superior) } & \multirow[t]{2}{*}{ Greenhouse, Windsor CT } & Length & 32.1 & 4.5 & 23.0 & 46.0 & $31.1-33.2$ \\
\hline & & Width & 16.3 & 1.7 & 13.0 & 20.0 & $15.9-16.7$ \\
\hline
\end{tabular}

a Each observation is the mean of a minimum of 100 measurements.

${ }^{\mathrm{b}} \mathrm{SD}=$ standard deviation.

c $\mathrm{CI}=$ confidence interval.

Table 2. Oidium lycopersicum conidia size $(\mu \mathrm{m})$ as influenced by current and previous host

\begin{tabular}{|c|c|c|c|c|c|c|c|}
\hline Current host & Previous host & Conidia & Mean $^{a}$ & $\mathbf{S D}^{\mathbf{b}}$ & Minimum & Maximum & $95 \% \mathrm{CI}^{\mathrm{c}}$ \\
\hline \multirow[t]{2}{*}{ Tobacco cv. C9 } & Tomato & Length & 30.0 & 3.0 & 25.0 & 40.0 & 29.4-30.6 \\
\hline & & Width & 17.7 & 2.2 & 12.5 & 23.8 & $17.3-18.1$ \\
\hline \multirow[t]{2}{*}{ Tomato cv. Rutgers } & Tobacco & Length & 34.2 & 4.3 & 25.0 & 47.5 & $33.3-35.0$ \\
\hline & & Width & 18.7 & 2.2 & 13.8 & 25.0 & $18.3-19.1$ \\
\hline
\end{tabular}

a Each observation is the mean of 100 measurements.

b $\mathrm{SD}=$ standard deviation.

${ }^{\mathrm{c}} \mathrm{CI}=$ confidence interval. 
necrosis, limited mycelial development, and sparse sporulation. Number of conidia per conidiophore averaged 1.96 (range 1 to 4) and $72 \%$ had 1 or 2 conidia per conidiophore. Infection of petioles was also observed.

There were significant differences in percent leaf infection and powdery mildew disease ratings between $L$. esculentum cultivars and Lycopersicon breeding lines under both greenhouse and field conditions (Tables 3 and 4). Most commercial tomato cultivars were severely affected by powdery mildew. Although cultivars such as Rutgers were not as extensively colonized by the fungus when compared to cultivars such as Celebrity and Nema 1200 , the severity of powdery mildew was still quite high. L. hirsutum and the tomato breeding line Hirol 3-21 were the only plants tested which were apparently resistant to $O$. $l y$ copersicum.

\section{DISCUSSION}

Powdery mildew of tomatoes may be caused by at least three different pathogens worldwide. O. lycopersicum can be readily distinguished from Leveillula taurica based on conidial morphology. On tomato, O. lycopersicum produces conidia singly or in short chains, and may be distinguished from $E$. orontii, which produces conidia in long chains (9). While the pathogen was first described in Australia in 1888 (3), the distribution of $O$. lycopersicum has recently been increasing in Europe (8) and in North America. Researchers from the United Kingdom $(5,12)$ reported a tomato powdery mildew with similar characteristics and host range to our isolates. A morphologically similar Erysiphe sp. disease has been reported from Quebec (1) and New York (6). Reports of an Erysiphe sp. from New Jersey (13) and Florida (10) may or may not be similar to the Connecticut isolates, as that fungus was reported to produce conidia in chains. An Erysiphe sp. from Hungary (7) produced conidia in chains and did not infect tobacco, which is different from the reported host range of $O$. lycopersicum from England (5) and from our findings in Connecticut. Additionally, we confirmed infection and symptom development on potato under greenhouse conditions, in agreement with previous researchers $(5,12)$ and the first report of this pathogen on potato in North America. Specimens have been submitted to the Connecticut Agricultural Experiment Station Herbarium.

Conidia size and morphology are most commonly used to differentiate powdery mildew species. However, size may vary greatly with host, host nutrition, and other environmental factors (15). O. lycopersicum has a remarkably wide host range of at least 13 plant families, including Cucurbitaceae and Solanaceae (12). Morphological characteristics were stable on tomato in the United Kingdom (12) and, in these experiments, with similar conidia sizes. There were fewer significant differences, however, between conidia length and width means from difference hosts in the United Kingdom $(n=30)$ than in our results $(n=100)$. We have demonstrated that the same isolate may vary considerably in conidia size on different host plants and that previous host may influence conidia size. In addition, the number of conidia per conidiophore may differ depending on the host plant. We confirmed reports that the same isolate may produce a greater number of conidia on tobacco than on tomato (5). Plant age, environmental conditions, or both may also affect host range, however, because we only observed infection on transplant-sized plants of eggplant and eastern black nightshade in the greenhouse and not on mature plants under field conditions. The fact that host and environment may affect the number of conidia borne per conidiophore may help explain the discrepancies in the literature concerning Oidium spp. on tomato.

This fungus was first described in 1888 (3) and appears to be widely distributed. However, cleistothecia of this parasite have yet to be found or induced. The fungus may be heterothallic, with only one mating type widely distributed. The teleomorph may not exist or may be present only in limited distribution. Whipps et al. (12) hypothesized that the recent expansion in O. lycopersicum distribution may be due to a recent development of a type aggressive to tomato that has rapidly spread around the world.

The increasing distribution of the pathogen and the severity of tomato powdery mildew on greenhouse-grown or fieldgrown plants under warm, humid conditions will require the development and evaluation of control tactics. A number of fungicides have been shown to be effective under field conditions in England (5) but

Table 3. Percent leaflet infection of selected tomato cultivars by Oidium lycopersicum under greenhouse conditions

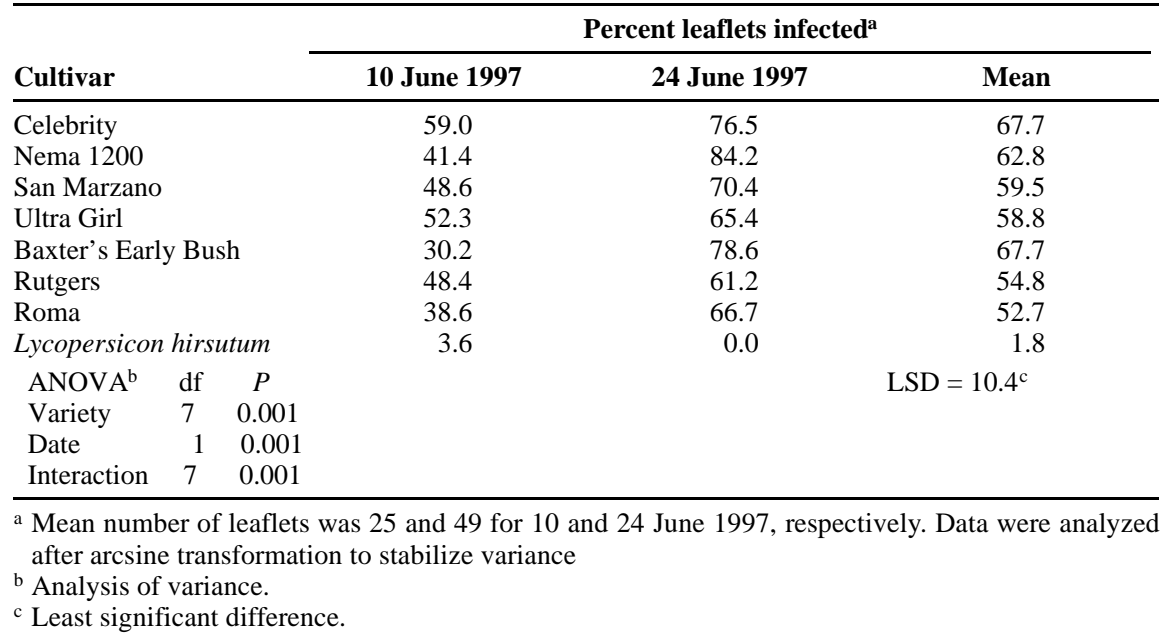

Table 4. Powdery mildew (Oidium lycopersicum) disease rating of selected tomato cultivars under field conditions

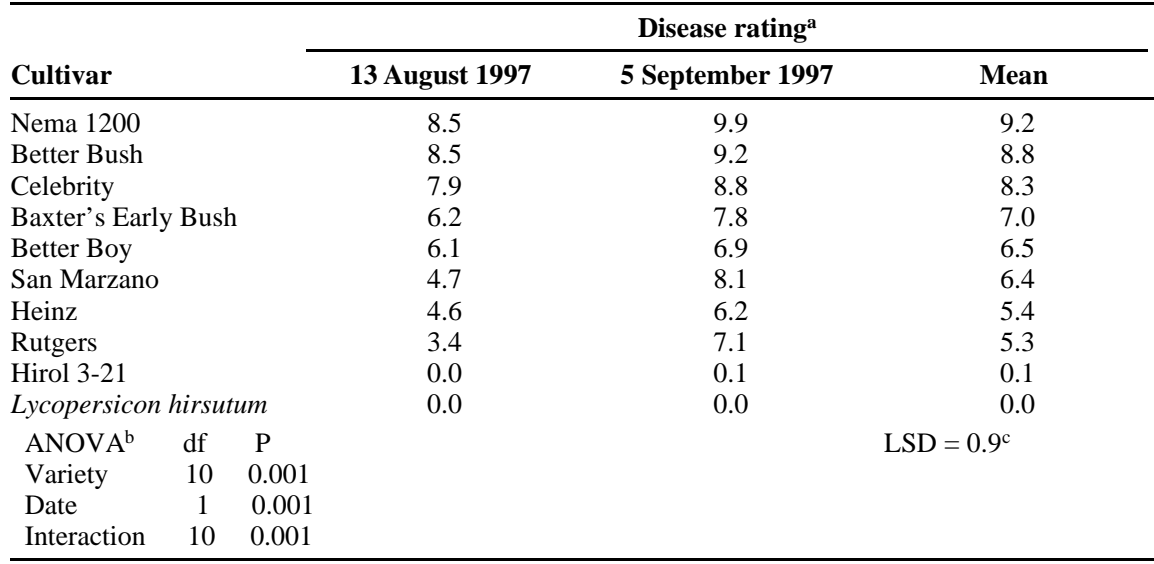

${ }^{a}$ Powdery mildew rating on a 0 to 10 scale $(0=$ none; $10=$ severe mildew $)$. Data were analyzed after square root of $x+1$ to stabilize variance.

b Analysis of variance.

${ }^{\mathrm{c}}$ Least significant difference. 
require evaluation in the United States. In general, commercial fields receiving fungicides have had reduced incidence and severity compared to unsprayed garden plots, but the disease is of concern to growers in integrated pest management programs. Breeding for resistance to O. lycopersicum has been initiated at Institut National de la Recherche Agronomique (INRA) in France (8). L hirsutum Plant Introduction (PI) 247087 has demonstrated near-complete resistance in France and in Connecticut. A breeding line designated Hirol 3-21 (tomato $\times$ PI 247087 back-crossed three times to tomato) has shown resistance in France and in Connecticut. This resistance appears to be oligogenic with incomplete dominance (8).

\section{ACKNOWLEDGMENTS}

We thank J. Canepa-Morrison, R. Ballinger, and R. Horvath for technical assistance; and H. Laterrot for seed of L. hirsutum and Hirol 3-21.

\section{LITERATURE CITED}

1. Belanger, R. R. 1994. Occurrence of powdery mildew (Erysiphe sp.) on greenhouse tomatoes in Canada. Plant Dis. 78:640.

2. Boesewinkel, H. J. 1980. The morphology of the imperfect states of powdery mildews (Erysiphaceae). Bot. Rev. 46:167-224.

3. Cooke, M. C. 1888. Australasian fungi. Grevillea 16:113-114.

4. Correll, J. C., Gordon, T. R., and Elliott, V. J. 1987. Host range, specificity, and biometrical measurements of Leveillula taurica in California. Plant Dis. 71:248-251.

5. Fletcher, J. T., and Smewin, B. J. 1988. Tomato powdery mildew. Plant Pathol. 37:594598.

6. Karasevicz, D. M., and Zitter. T. A. 1996. Powdery mildew occurrence on greenhouse tomato plants in New York. Plant Dis. 80:709.

7. Kiss, L. 1996. Occurrence of a new powdery mildew fungus (Erysiphe sp.) on tomatoes in Hungary. Plant Dis. 80:224.

8. Laterrot, H., Moretti, A., Conus, M., and Mas, P. 1995. Breeding for Oidium lycopersicum resistance. Rep. Tomato Genet. Coop. 45:30.
9. Noordeloos, M. E., and Loerakker, W. M 1989. Studies in plant pathogenic fungi-II. On some powdery mildews (Erysiphales) recently recorded from the Netherlands. Persoonia 14:51-60.

10. Pernezny, K. 1998. Powdery mildew of fieldgrown tomato in Florida. Plant Dis. 82:262.

11. Smith, V. L., Douglas, S. M., and LaMondia, J. A. 1997. First report of powdery mildew on tomato caused by an Erysiphe sp. in Connecticut. Plant Dis. 81:229.

12. Whipps, J. M., Budge, S. P., and Fenton, J. S. 1998. Characteristics and host range of tomato powdery mildew. Plant Pathol. 47:3648.

13. White, J. F., Jr., and Johnson, S. A. 1997. First report of powdery mildew in greenhouse-grown tomatoes in New Jersey. Plant Dis. 81:227.

14. Wickes, T. J., and Clare, B. G. 1981. Powdery mildew on tomato. Australas. Plant Pathol. 10:36.

15. Yarwood, C. E. 1978. History and taxonomy of powdery mildews. Pages 1-37 in: The Powdery Mildews, D. M. Spencer, ed. Academic Press, London. 